\title{
Authentic Materials and Tasks as Mediators to Develop EFL Students' Intercultural Competence
}

\author{
Materiales auténticos y tareas como mediadores para desarrollar \\ competencias interculturales en estudiantes de inglés
}

\author{
Bernal Pinzón, Alix Norely ${ }^{1}$
}

\begin{abstract}
This article reports on a study carried out in a foreign language course at a private Colombian university. Its purpose was to identify the role of authentic materials and tasks, based on cultural topics, in the development of intercultural competence in third-level English students. The pedagogical implementation of the activities was designed under criteria proposed by Cortazzi and Jin (1999) to evaluate the material with cultural content. In regard to intercultural competence, Byram's (2002) dimension of intercultural communicative competence was the support for planning and implementing the tasks. In this qualitative action research study, two surveys, one interview, and teacher field notes were used to collect data. Findings indicate that students were able to understand interculturality, to show respect for other cultures, and to demonstrate interest in getting to know other societies. Likewise, the students reported their willingness to be open to discussing topics related to cultural aspects.
\end{abstract}

Keywords: authentic materials, authentic tasks, cultural content, intercultural competence.

\section{Resumen}

Este artículo reporta un estudio desarrollado en un curso de lengua extranjera en una universidad privada colombiana. El propósito principal era identificar el rol que los materiales auténticos y las tareas basadas en contenidos culturales tienen en el desarrollo de competencias interculturales en estudiantes de inglés de tercer nivel. La implementación pedagógica de las actividades fue diseñada bajo el criterio propuesto por Cortazzi y Jin (1999) para evaluar el material con contenido cultural. En lo que respecta

Alix Norely Bernal Pinzón is an English teacher, she currently works at Universidad Pedagógica y

Tecnológica de Colombia in the Faculty of Distance Studies. She holds an MA in language teaching. alix.bernal@uptc.edu.co

http://orcid.org/0000-0002-9732-6028

Received: April 1st, 2019. Accepted: December 19th, 2019

This article is licensed under a Creative Commons Attribution-Non-Commercial-No-Derivatives 4.0 International License. License Deed can be consulted at https://creativecommons.org/licenses/by-ncnd $/ 4.0 /$ 
a la competencia intercultural, planeación e implementación de las tareas, se tomó como referencia el modelo de las dimensiones de la competencia comunicativa intercultural de Byram (2002). En esta investigación acción dos encuestas, una entrevista y los diarios de campo de la docente fueron usados para la recolección de datos. Los hallazgos indican que los estudiantes son capaces de entender la interculturalidad, de demostrar respeto por otras culturas y manifestar interés para aprender sobre estas. De la misma manera, mostraron una actitud abierta para discutir temas relacionados con la cultura.

Palabras clave: material auténtico, tareas auténticas, contenidos culturales, competencia intercultural.

\section{Introduction}

According to Hymes (1996), language plays a crucial role in the social life of a community; a lack of cultural understanding among members of several communities often leads to social inequality that has yet to be recognized. This statement should make language teachers reflect upon the importance of knowing how to communicate with a member from a different culture; understanding that different culture does not mean only the target language culture but also students' culture, bearing in mind that they bring to the classroom their own beliefs, their conceptions about life, etc. Likewise, English language teachers need to have in mind that learning a foreign language goes beyond acquiring linguistics habits and grammar structures; it is also about learning how to communicate with others by using the target language, interacting with others, and also recognizing the value of their own culture.

English language classes ought to be a space to develop intercultural competence in students in regard to making language teaching an interdisciplinary matter in which culture is a fundamental component. For instance, Agudelo (2007) reports his experience teaching a course titled "Language, Culture, and Diversity" at a language teacher preparation program in Medellin with seventh-semester students. His purpose was to find out the impact of the use of an intercultural approach. Agudelo (2007) claimed that the implementation of an intercultural approach for language teaching sought to help future language teachers understand not only the multiple socio-cultural factors implied in teaching a foreign language, but also the importance of critical cultural awareness to be able to understand other cultures without losing perspective of the local reality. Thus, from this perspective, the exploration of the local culture was as valid and necessary as that of the target culture.

To explore this topic in more depth, I took into consideration my previous knowledge from teaching the English language; I started to consider other ways to address the topics to call students' attention and to offer them means to become respectful subjects able to interact effectively in an ever changing society. Research questions and objectives were set under a qualitative action research; two surveys, a semi-structured interview, and teacher field notes were used to collect data with the purpose of answering the question: What is the role 
Authentic Materials and Tasks as Mediators to Develop EFL Students' Intercultural Competence

of authentic materials and tasks, based on cultural topics, in the development of intercultural competences in third-level English students at a private university?

\section{Literature Review}

In this section the main constructs that ground this experience are presented. They are: authentic materials, and tasks, culture in an EFL classroom, and intercultural competence.

Authentic materials. The use of authentic materials in EFL classrooms may be useful for teachers and students to develop not only grammatical skills but also to reinforce students' ability to understand and contextualize the language used in the classroom and the language people use in other social contexts. Furthermore, English language teachers can develop their creativity when designing and adapting material to promote more learning of the target language and its use.

For the development of this project, authentic materials are taken as the material that is not designed for teaching purposes; it means that the material utilized is not commercially produced to teach a target language itself, which can include EFL/ESL textbooks, audiotapes, workbooks, worksheets, etc. As a matter of fact, the authentic material utilized was American and Colombian currency (bills and coins), movies, and history texts about religions. Furthermore, the students participating in the study had the opportunity to share what they had learnt from those tasks with their classmates. These students designed and used posters, brochures, and videos for sharing what they had learnt from the tasks developed.

Porter and Roberts (1981) show several differences between authentic materials and nonauthentic materials in terms of spoken language. For example, conversations recorded for language texts often have a slow pace, have particular structures which recur with obtrusive frequency, and have very distinct turn-taking of speakers. Also, hesitations (such as "uh's" and "mm's") are often missing, and sentences are very well-formed with few if any mistakes. In other words, what the language learners hear in class is different from the language in other social contexts.

In one of the semi-structured interviews, for instance, the participating students claimed feeling nervous when speaking in English due to feeling afraid of making mistakes or misusing the grammar rules. In many cases, the language heard in EFL classrooms is a stilted use of spoken English; the real objective of teaching this language is lost because of a need to teach specific language points in a method that some teachers may feel would be more understandable for learners.

Nunan (1999) also defines authentic materials as spoken or written language data that have been produced in the course of genuine communication, and not specifically written 
for purposes of language teaching. In fact, in his teaching practices, he encourages students to bring into the classroom their own samples of authentic language data from "real-world" contexts outside of the classroom. In this sense, the use of authentic materials to address cultural topics in an EFL classroom allows students to practice "real" language, to listen to different accents, understand their classmates, and make themselves understood.

The main idea for developing this research project was then to encourage the participating students to develop their intercultural competence by using English as a means to express ideas, feelings, and opinions; and to bring the "real world" into the classroom in terms not only of the English language but also as a space to exchange intercultural encounters. This purpose looked to help the participating students become more critical about happenings in our country and the world.

Contradictorily, authors as Kilickaya (2004) claim that authentic materials add a burden on teachers as these may contain difficult vocabulary and structures that need more effort to be simplified to make them appropriate for their learners. This statement helped me, as the researcher, to analyze the role of authentic materials on the participating students before, during, and after developing the task, and also to think about the questions students should be asked.

I always asked my students how they felt using that kind of material, how hard it was to read and understand, and to write about. During the development of the tasks, I became a support for my students i.e. I always made sure that they understood the materials. Using authentic materials in an EFL classroom is not an easy task, but time consuming; however, English language teachers should support language learning and help learners value their own culture and avoid generalizations among other cultures.

Authentic tasks. Scholars such as Brown and Menasche (as cited in Shoomossi \& Ketabi, 2007 , p. 152) provide a controversial view of authentic tasks by noting that "there is probably no such thing as 'real task authenticity' since classrooms are, by nature artificial." However, Widdowson (as cited in Mishan, 2005, p. 98) claims that "it is the relationship between the learner and the input text, and the learner's response to it, that should be characterised as authentic, rather than the input text itself." Thus in foreign language learning contexts, where exposure to the language being learned is scarce, English language teachers should create spaces within the classrooms with the objective of making students have access to authentic tasks that permit them to study the language structure and to focus on more than one skill at the same time.

Through my experience, it was common to assign pedagogical tasks to students to grade them about a single grammatical structure and almost always by using only one skill per task; as a result, students came to believe that the English language was something they learned by pieces and not being able to use it to know or talk about their own culture and others'. 
Thus, there was an imperative need to implement tasks which would facilitate learners to meaningfully and purposefully use English within varied contexts and contents, valuing these rather than merely grammar structures.

Language and culture in an EFL classroom. The integration of culture in language teaching is based on the assumption that one cannot be explored without the other; they are interrelated (Kramsch, 1998; Lesow-Hurley, 2000; Sellami, 2000). Teaching culture is certainly not a recent idea; on the contrary, there is a history of the use of culture while teaching a foreign language. According to Lessard-Clouston (as cited in Thanasoulas, 2001, p. 3), "In the past, people learnt a foreign language to study its literature, and this was the medium of culture." This is why language learners had to read extensive literary books such as Romeo and Juliet or Hamlet. By reading these literary books, they were supposed to learn the structures of the target language and the expressions that speakers of that language were more likely to use.

Nowadays, in Colombia, in the Foreign Language Teaching (FLT) field, there have been studies related to addressing culture and interculturality. Those studies cover materials to develop ICC (Rico, 2012), the development of intercultural competence skills (Ramos, 2013), critical intercultural learning through topics of deep culture in an EFL classroom (Gómez Rodriguez, 2015, and the cultural content in EFL textbooks (Granados-Beltrán, 2016). Although the topic of intercultural competence has interested English language teachers in Colombia, the reality of these teachers' practices may be different; the teaching of language forms may continue being the focus (Alonso \& Fernández, 2013).

That is the case of the private university where this current study took place. According to the design of its syllabus, English language is still seen as a subject to be taken for graduation requirements, learners focus on studying grammar structures and getting ready to take a test that assesses their knowledge about those grammar rules learnt in the English language classes. Thus, culture in this context is not in their goals as addressing culture in the English language classroom. As a consequence, learners give much priority to test scores since passing the courses is a requisite for their degree.

Considering the Colombian Ministry of Education, one can say there is no teaching of a language without teaching the culture of that language. Language teachers may sometimes forget the real necessity of learning a target language: the importance of using languages to know the differences and commonalities that people have around the world by becoming more respectful and responsible citizens.

Intercultural competence. I understand this concept mainly from the definition given by the Common European Framework of Reference (CEFR) (Council of Europe, 2001) and from a teacher's guide to IC (Byram, Gribkova, \& Starkey, 2002). The reason for using these sources is that they both have nurtured this research project on how to address culture in 
an EFL classroom. When looking at what the CEFR says on intercultural competence, it first mentions intercultural awareness. It means that an individual is aware of the fact that people belong to many social communities, wherein national culture is one of these (Council of Europe, 2001). Intercultural awareness refers to "an understanding that two people from the same country do not share the exact beliefs or traditions because of merely sharing the same national culture" (p. 103). This type of thinking promotes the perception of people from other countries as complex individuals and aims to inhibit a way of thinking in which people are perceived through national stereotypes.

Byram, Gribkova, and Starkey (2002) give a more detailed definition of intercultural competence (IC) by first explaining the concept and by mentioning the component of IC; hence, we understand or see what is needed in order to say that someone is interculturally competent. These authors describe IC communication as based on respect and understanding of different cultures without only judging the conversational partner from the culture he or she comes from. To be able to perform this type of communication, they argue that "the individual needs to develop a competence within three components, which are considered to be IC components: Skills, knowledge and attitudes" (Byram, Gribkova, \& Starkey, 2002, p. 10).

The knowledge component refers to knowledge about cultural aspects of the target culture (Byram, Gribkova, \& Starkey, 2002, p. 12). The attitudes refer to the willingness of the individual to understand, which is the basis of achiving IC, since negative attitudes towards exploring and familiarizing oneself with different cultures will result in not actually understanding them. The third component, skills, refers to the procedural knowledge of IC that an individual needs to develop. It includes the competence of being able to relate to different aspects in the target culture, and in that way get a better understanding of the target culture.

For this research project the three concepts of intercultural competence were taken into consideration. Those concepts supported me, as the researcher, at the time of deciding about the tasks carried out during the period of the development of the tasks. At the pre-task, the participating students were exposed to cultural aspects from the target culture and their own home culture so that they were able to get more familiar with the topics; then, during the task, the students could addresse cultural topics through oral presentations and written reports. Likewise, during the post tasks, they had the opportunity to include some sort of reflection on what was studied.

\section{Research Participants and Context}

This project research was carried out in an English language class with students from sixth semester, third level, at a private university in Tunja, Colombia. There were 22 students, 13 females and 9 males. The university offers three mandatory levels of English 
in its 21 academic programs. After taking the three levels of English, students ought to take a proficiency test that is designed by the language department, based on its syllabus, as a requisite for the attainment of their degree.

A series of tasks adapted from the taxonomy of intercultural activities proposed by Alonso and Fernández (2013), based on Byram's ICC model (2002), was designed for the study (see Table 1 above). This design also considered theories about authentic materials in an EFL classroom, as the ones by Brinton (1991) and Gebhard (1996), who see authentic materials as a way to bring real language into the English classroom. For this study, authentic tasks were taken into consideration as an approach to include the participants in comprehending, manipulating, producing or interacting within the target language, while their attention was on mobilizing their grammatical knowledge to express meaning (Nunan, 1999, p. 25).

The English language classes are heterogeneous; students come from different backgrounds and their ages range from twenty to twenty-six years old. They have medium socio economic status. This level of English was created with the aim of helping students to reinforce what they had learnt during the previous two levels of English. The syllabus is designed based on the two previous levels.

\section{Research Methodology}

The activities proposed to find an answer to the research question of this study were planned for development over a month and a half. The tasks were adapted from the taxonomy of intercultural activities proposed by Alonso and Fernández (2013), based on Byram's (2002) model of ICC, as seen in Table 1 below. The activities also follow the model for EFL materials development and the use of authentic materials for beginner students (Guariento \& Morely, 2001).

Instruments and procedures for data collection. Two surveys were applied, one at the beginning of the course and the other at the end of the course; also, an oral semistructured interview and teacher's field notes were used to collect data. These instruments compiled the students' insights and the teacher's perceptions about the activities carried out during the study. Furthermore, these instruments were a great support for identifying the most suitable information that was oriented toward giving an answer to the question and reaching the objectives of the present study.

By taking the research question into consideration, the data were analyzed through the coding process suggested by Patton (2002). This process helped identify the participants' production of similar opinions, themes, and thoughts that gradually became representative patterns in the whole data. That is to say, the coding process is a grounded approach method 
(Freeman, 1999) that prompts one to examine the data several times with the objective of triangulating the information collected and defining patterns.

In this sense, the analysis of data was done following the Grounded Theory data analysis (Freeman, 1999). It is a data analysis procedure in which the theory emerges from the data. Afterwards, making notes about the researcher's first impressions, labeling relevant words, phrases, sentences or sections were necessary. Subsequently, deciding which codes were the most important to create categories by bringing several codes together was done. Two categories emerged. To ensure trustworthiness, the information was triangulated by dragging information from all the sources to the categories previously identified "to minimize the danger of a one- sided representation" (Richards, 2003, p. 251).

Once the patterns were identified from the participants' responses about the tasks developed and the material used, the statement of themes took place in such a way that those categories represented the students' insights about the target language culture, their home culture, the tasks, and the topics. The participants' names were kept confidential by using fictional names in the findings.

\section{Findings}

Data collected demonstrated that the implementation of authentic materials and tasks constructed on cultural aspects promoted the development of certain behaviors and attitudes surrounding interculturality. For instance, the participating students were able to compare other cultures, practices, and representations with their own. They pinpointed stereotyped representations that other cultures may have towards us, and that Colombians may have towards other cultures. Also, they manifested willingness to find out more information of their own culture and other cultures (this is more elaborated on below).

Tudor (2001) affirms that teaching materials cannot be neutral because they have to reflect a "set of social and cultural values which are inherent in their make-up... and explain a value system, implicitly and explicitly" (p. 73). In the process of carrying out the tasks, it was visible that despite learners not having the sufficient level of vocabulary to give their opinions in English, they had developed their thoughts about specific topics. For instance, when one of the students asserted that it is common to find on the bills only politicians, not "regular" people. That comment made other learners realize a common feature that the United States and Colombia currency have. And also it made them wonder about an item they probably had not thought about before.

Next, I present the three main categories that emerged during data analysis to answer the research question: What is the role of authentic materials and tasks, based on cultural topics, in the development of intercultural competences in third-level English students at a private university? 
Table 1. Implemented Tasks

\begin{tabular}{|c|c|c|c|}
\hline Criteria & Tasks & $\begin{array}{l}\text { Intercultural } \\
\text { Component }\end{array}$ & $\begin{array}{c}\text { Authentic } \\
\text { Material }\end{array}$ \\
\hline $\begin{array}{l}\text { 1. Beliefs and be- } \\
\text { havior: moral, } \\
\text { religious beliefs, } \\
\text { daily routines }\end{array}$ & $\begin{array}{l}\checkmark \text { Getting to know some of the } \\
\text { greatest religions in the world. } \\
\checkmark \text { Students read one of the religions } \\
\text { in groups of four and learners } \\
\text { will find information as a short } \\
\text { background of the religion, } \\
\text { rituals, beliefs and traditions. } \\
\checkmark \text { Students also talk about their } \\
\text { experiences about their religious } \\
\text { beliefs, why they believe or not. }\end{array}$ & $\begin{array}{l}\text { Knowledge } \\
\text { (savoir) } \\
\text { Attitudes } \\
\text { (savoir être) }\end{array}$ & $\begin{array}{l}\text { Excerpts } \\
\text { from a } \\
\text { book called: } \\
\text { The Greatest } \\
\text { Religions in } \\
\text { the World }\end{array}$ \\
\hline $\begin{array}{l}\text { 2. National His- } \\
\text { tory: historical } \\
\text { and contempo- } \\
\text { rary events seen } \\
\text { as makers of } \\
\text { national identity }\end{array}$ & $\begin{array}{l}\checkmark \text { States from the USA. } \\
\checkmark \text { Students were given a coin from } \\
\text { the United States, then, they } \\
\text { have to look up for specific } \\
\text { information about a state. }\end{array}$ & $\begin{array}{l}\text { Knowledge } \\
\text { (savoir) }\end{array}$ & $\begin{array}{l}\text { Currency } \\
\text { from the } \\
\text { United } \\
\text { Sates } \\
\text { (coins) }\end{array}$ \\
\hline $\begin{array}{l}\text { 3. National His- } \\
\text { tory: historical } \\
\text { and contempo- } \\
\text { rary events seen } \\
\text { as makers of } \\
\text { national identity }\end{array}$ & $\begin{array}{l}\checkmark \text { Coins and bills from Colombia. } \\
\checkmark \text { Students had to investigate } \\
\text { some historical facts about the } \\
\text { person who appears on the bill } \\
\text { as well as the representative } \\
\text { animal that are on the coins. }\end{array}$ & $\begin{array}{l}\text { Knowledge } \\
\text { (savoir) } \\
\text { Skills } \\
\text { (savoir engager) }\end{array}$ & $\begin{array}{l}\text { Currency } \\
\text { from } \\
\text { Colombia. } \\
\text { (coins and } \\
\text { bills) }\end{array}$ \\
\hline $\begin{array}{l}\text { 4. Social Identi- } \\
\text { ty and Social } \\
\text { groups: social } \\
\text { class, regional } \\
\text { identity and eth- } \\
\text { nic minorities }\end{array}$ & $\begin{array}{l}\checkmark \text { Students watched a movie related to } \\
\text { a tribe in Somalia and its traditions. } \\
\checkmark \text { Students were exposed to } \\
\text { African and English accents. }\end{array}$ & $\begin{array}{l}\text { Knowledge } \\
\text { (savoir) } \\
\text { Skills } \\
\text { (savoir engager) }\end{array}$ & $\begin{array}{l}\text { Movie: The } \\
\text { Desert Flower }\end{array}$ \\
\hline $\begin{array}{l}\text { 5. Social Identi- } \\
\text { ty and Social } \\
\text { groups: social } \\
\text { class, regional } \\
\text { identity and eth- } \\
\text { nic minorities }\end{array}$ & $\begin{array}{l}\checkmark \text { Students watched a movie } \\
\text { about a Latin woman who is a } \\
\text { guest in a business dinner. } \\
\checkmark \text { They saw types of interaction among } \\
\text { people as to how they treat each } \\
\text { other that belong to the same circle } \\
\text { and how they treat a woman who } \\
\text { does not belong to that circle. }\end{array}$ & $\begin{array}{l}\text { Attitude } \\
\text { (savoir être) }\end{array}$ & $\begin{array}{l}\text { Movie: } \\
\text { Beatriz at } \\
\text { Dinner }\end{array}$ \\
\hline
\end{tabular}


The first category refers to how the participating students demonstrated their understanding of interculturality as something different in all cultures and how they recognized others and valued their home culture. That first category was named Towards Understanding Interculturality. Two subcategories emerged: Appraising students' homes and establishing relationships. The second category denotes Thinking from another perspective towards other cultures and their home culture; a subcategory belonging to this category is evaluating differences.

Category 1: Towards understanding interculturality. The participating students began to notice that there were many things they did not know about their own culture. Schools and universities sometimes do not contribute to addressing those topics in class, exploiting the resources they have access to, debating about history, and sharing students' backgrounds with the aim of making students think in their culture. The importance of having those sorts of topics in an English language class was evident in a question about the intercultural topics carried out in the English class ${ }^{2}$ :

Maria: I found the tasks interesting, I have known about my culture. For example, the coins and bills, we do not pay attention to those things, we just talk about the new coins, but we are not interested in getting to know what they symbolize. Until someone comes and says, look what you bave. Then, we start thinking about what we have. (Interview 1. Q1).

In this sense, the students started recognizing the lack of knowledge about their home cultures in an English language classroom and outside of it; furthermore, they commented that some topics which they thought were familiar to them due to the use they give them every day as are the bills and the coins; they realized they were unfamiliar when asked for first time about the characters and the symbols that were on them. As Maria mentioned the coins and bills as something that everybody had in their hands, but it was like nobody was interested in looking at them and investigating who those people were printed on the bills, or those animals on the coins. The use of authentic materials in the English classes not only provided new vocabulary and presented the grammatical rules to the students, but also they permitted the participants to explore topics about which they probably had no idea. It can be evident in the following excerpts.

Carolina: It think is good to have this topics in the English class because we learned many things about other countries and our country. For instance; I did not know about the Guacari tree, that the five-hundred-peso coin has, I did not know that it paid homage to it. I did not know it was a Colombian tree and neither knew about the spectacled bear, that it lives in Boyaca. (Interview1. Q1).

Lina: When I read about the spectacled bear; I found that it is in danger of extinction, after reading that I realized... I did not know he was in danger of extinction. And, what are we doing wrong for this to happen? (Interview 1.Q5).

2 Students' responses were translated for publication purposes.

HOW Journal 
Authentic Materials and Tasks as Mediators to Develop EFL Students' Intercultural Competence

In the same way, in the task related to coins and bills from the United States and Colombia, the students said:

It was good to know about the USA coins but was also important to know about our coins; we have never done an activity in which we talk about our country in an English class. (Teacher's field notes \# 4).

Along with the statement above, English language teachers can certainly utilize more authentic materials inside the language classrooms, to let students not merely use the target language but also learn new things about their own context, all by using the target language as a mediator to increase their knowledge and develop their curiosity.

Mauricio: It was nice to know about other cultures but also to know about my department; there were many things I did not about my department. (Survey 2. Q3)

Maria: I rned things I did not know about my department, and I was born there in Casanare. (Interview 1Q5)

Additionally, the use of authentic materials in an EFL classroom permits students to learn culture in depth and to avoid stereotypes; also to comprehend their history and to value their cultural backgrounds. The utilization of authentic materials is not an easy task, it is time consuming; however, it is worthy to see learners being motivated trying to use the language, learning not only new words but also learning facts that make them feel important, as was seen in Mauricio's and Maria's responses above when they said that they did not know many things about their hometowns.

Appraising students' bome. This subcategory emerged from the repetition of patterns in the survey, interview, and teacher's field notes. When the students reacted to the culturebased materials, they challenged home culture policies, acknowledged some aspects of the foreign culture represented in the materials, reshaped their beliefs, expressed surprise, reshaped views of the foreign cultures, compared the cultures they were exposed to, and valued the richness of their own culture. Some examples are the following:

[After watching the movie Beatriz at Dinner one student commented:]

I liked that she feels so proud of her culture and her background. I thought about us as Colombians, we sometimes feel embarrassed about many things; for example: to dance Carranguera music or to say that we are farmers or that we are poor... Most of us try to be another person. (Teacher's field notes \# 5)

This movie caused the students to reflect upon the role Latin people play in a country as the United States. They could see themselves reflected in the main character; a person who was a hard worker, took care of the environment, and had a dissimilar way to see life from those who were her guests. The main character was raised in Mexico with very similar values as people from Colombia, whereas wealthy people were raised to have the power, to have a recognizable status in society. That is why there were comments as: 


\section{"T liked that she feels so proud of her culture and her background."}

This shows that the students, by watching this movie, recognized the worth of their home culture in relation to its values and family nearness; they made comparisons with the American culture, especially with the family in the movie; they recognized the qualities and the richness their home culture had. In addition, a student illustrated:

"I thought about us as Colombians, we sometimes feel embarrassed about many things; for example: to dance Carranguera music or to say that we are farmers or that we are poor... Most of us try to be another person."

He included himself as part of those Colombians who sometimes feel embarrassed of accepting their backgrounds. Certainly, the movie, one way or another, made the students appreciate their roots and culture more; they thought that their culture probably had other valuable things that probably other cultures lacked.

Along the same lines are Maria's and Mauricio's opinions:

Maria: We sometimes try to follow stereotypes, I mean to copy things from other cultures, and we don't know the beautiful things that our country has... ah there are many things we feel embarrassed about... (Interview 1 Q2).

Mauricio: To value what I am and who I am. (Survey 2 Q5).

They completely approved the opinion above; they started comparing their home culture with the one represented in that wealthy family in the movie: that most of the time showed a family that cared a lot about showing off in a consumer society. Those types of families are rarely presented in textbooks or contrived material. Exposing learners to this kind of materials makes them think critically about other cultures and their home culture. They increase not only students' knowledge about vocabulary and grammar, but also other perspectives and ways of living.

Establishing relationships. By means of reading the data, it was seen that when the students began understanding interculturality, they started thinking more openly about other cultures. It was represented in their opinions about respecting other cultures and other points of view. In addition, they showed their intention to investigate their home cultures and other cultures with the purpose of understanding the world as a place that is full of practices, 40 beliefs, thoughts, and diverse peoples. This can be visible in the students' responses to the questions about what they had taken or learned from the tasks based on culture:

Berenice: To respect the differences, to see that there are many people in the world that think differently and that live different. (Survey 2. Q5)

Carolina: I have always thought that one must respect other ways to think and believe in order for them to respect our beliefs too. As I read about the Amish, they believe in God but in an old manner; and that they believe that way ummm it is ok, they come from another culture. (Interview $1 Q^{4}$ ) 
Authentic Materials and Tasks as Mediators

to Develop EFL Students' Intercultural Competence

During the round table discussion, when the students were discussing religions; one of the students commented:

It is important to respect those beliefs, because our parents believed that, because of our ancestors." (Teacher's field notes \# 1)

As is evident in Carolina's opinion, when she said, "They come from another culture," one can infer that what she tried to explain was the fact that people come from different social groups, which shape the way they think, feel, or behave. Also, this student's comment during the development of a task reinforced that idea (Because our parents believed that, because of our ancestors" [Teacher's field notes \# 1]). By having in mind the students' opinions in regard to how they saw others, the data showed that they were developing their awareness of similarities and differences among themselves.

As Stern (as cited in Kumaravadivelu, 2003, p. 216) claims: "One of the most important aims of culture teaching is to help the learner gain an understanding of the native speaker's perspective." It is a matter of the L2 learner "becoming sensitive to the state of mind of individuals and groups within the target language community" (p. 217). In the study, all of the participating students commented in their responses on the importance to investigate whenever a topic is not well known.

This clearly demonstrates that, when students are exposed to intercultural topics and have the opportunity to talk and see themselves from another perspective, they begin developing an understanding and a sense of respect together with tolerance in the direction of others as unique individuals. They also think about their own beliefs as a way to continue with their traditions and belong to a certain social group. Those opinions can be verified in the teacher's field notes; when the students were sharing their knowledge about religions in a round table discussion, there was a comment by one of the students:

"Most religious people do not know with certainty why they belong to a specific religion" (Teacher's field notes \# 4).

This opinion was given when the student asserted that he did not belong to any religion because he did not know why people had religions. The interesting point here is that, at the beginning, they just started sharing what they had found in the readings and talking about what had surprised them. Then, when this student gave his outlook about religions and the reason why he did not believe in any religion, they started talking among themselves, analyzing wars and how human beings took advantage of people's beliefs to sometimes discriminate against others:

Mauricio: One starts to understand that each religion has a supreme being and it is seen from different perspectives; and start understanding better the problematic situation that is caused by religions; it should be 
that way, since the buman being should be more comprehensive and instead of being excluded being included. (Interview 1, Q4).

As Cope and Kalantzis (2000, p. 18) assert: "learning to be intercultural involves much more than just knowing about another culture, it involves learning to understand how one's culture shapes perceptions of oneself, of the world, and our relationship with others." English language teachers ought to comprehend the importance of giving students the opportunity to recognize their own culture, to value and to understand how the place where they were born, their families' beliefs and customs have shaped their identity and the way they interact with others.

That evidence of understanding culture was not only demonstrated in the students' responses to a set of questions asked by the teacher, but also in the development of the classes, when they had to work in groups of three of four, and had to cope with classmates that had different opinions or understood differently what they were trying to extract from the material. In these cases, most of the students showed respect towards different estimations since they saw their partners as representatives of dissimilar cultural backgrounds.

Category 2: Thinking from other perspectives. This category appears after one notices the participating students' repetition about the importance of trying to see different perspectives before judging others. It was remarkable, overall, after watching the movie Beatriz at Dinner; they had to represent one of the characters of the movie and be in his/her shoes. This task allowed them to analyze why people think, act, and are different depending on their backgrounds and past experiences. Hearing some of the students identify their own feelings through the main character's emotions about a particular situation was remarkable. It implies that the students started to develop empathy since, in their opinions, they did not seem to judge the behavior of anybody in the movie; instead, they tried to think from their perspectives without judging. There were opinions as:

It was interesting being in Beatriz' and Frank's shoes. It was difficult to analyze the whole situation, because we give opinions about people, but we do not know what is behind them; or we do not give them the opportunity to know them just because we do not like them, as Beatriz did with Frank. (Teacher's field notes \# 5).

Berenice: "It is important to analyze the situations and analyze people, above all when we do not know them very well, because we only see a little part of those people" (Interview 1 Q 3).

Mauricio: We could see from the activities we developed that all of us are different, we Colombians or Boyacenses are different, and we should not judge others. Instead of doing that, we must know and accept others' opinions without judging (Survey 2 Q 5).

These comments show that most of the students were able to identify problematic representations that people in the movie held of other cultures and of their own. Importantly, the students did not assume the role of judges when developing the tasks in which they had to put themselves in the shoes of one of the two main characters of the movie. Their 
attitude towards others was flexible and they concluded (or agreed?) on the importance to be open to other opinions, to be strong when defending their thoughts; they mostly talked about the need to not judge without thinking.

Most of the students seemed motivated to participate and give their opinions. For this task, the students worked in groups of four people; they chose a character and prepared their presentations. The teacher helped them in constructing their sentences and pronunciation. Moreover, the teacher and students negotiated language: they were allowed to use Spanish when they wanted to clarify something or to make themselves understood. In one of the group discussions, the students were talking about situations or contexts in which they could see people behaving like Beatriz or Frank. And one of them said:

"There are people very insistent in trying to convince others to think the way they think. That happens with religions and politics". (Teacher's field notes \# 5)

This kind of data confirms that when learners are exposed to authentic materials and cultural tasks, they use those opportunities to be critical, to express and understand the diverse points of view which enhance their perspectives, make them analyze and accept differences, and be able to recognize commonalities among other cultures. As Kramsch (1999) clarifies, an intercultural speaker is a tolerant and open-minded person who is able to interact with other cultures by taking into account cultural differences.

English language teachers thus need to use their classrooms to approach this sort of situations that people may experience every day, especially in university contexts. This practice can provide learners with the development of other skills, not only the ones proposed by the syllabus, but the ones they need to have to become integral people, be respectful and tolerant, listen to others, and act according to their principles. This is possible to do if teachers distribute their classes teaching what the program claims.

Robinson (1998) and Cheung (2001) state two types of knowledge that take place inside schools: one is related to the subject matter and the other is concerned with the world. English language teachers are faced with the need to support developing intercultural competence in the classrooms. For the development of this study both types of knowledge were kept in mind when applying the tasks.

\section{Conclusions}

The present study revealed that when students are exposed to authentic materials and also to tasks based on culture, they have the opportunity to develop their intercultural competence, to expand their knowledge not merely in the language as a code but also to be exposed to real language, to real situations that happen in their contexts. As a matter of fact, there are changes on how students perceive the learning of a language and how important it 
is having something to say in that foreign language, not only to know how to label things in the English language but actually to put together vocabulary to express ideas.

English language teachers play a relevant role in helping students understand the reality they are living and reshaping regarding their ways of thinking or the way they perceive the world. Throughout my experience, it was always a concern how I could support students in their growth as human beings and professionals. There was a need to provide different English language lesson plans to permit students to develop their curiosity, be better listeners and, overall, recognize themselves as part of a society that needs more respectful, tolerant and critical social beings.

Based on experiences throughout the course, the use of authentic materials should begin when students are in their first level of English language learning, so that this practice can enable them to develop the habit of using different sorts of materials. In fact, English langauge teachers ought to begin with short stories, comics, recipes, menus, songs or excerpts taken from books to get students accustomed to having contact with "real" language. As a result, when they get in higher levels, the use of this material can increase their contact with the target language and culture.

Learners' insights showed that if they feel challenged, they will find the way to solve the grammatical abundance from the authentic material. Nonetheless, English language teachers need to take the time to read the material before bringing it to the classroom. They need to see if it requires adaptation for students so that they will not feel overwhelmed with the richness of the vocabulary. In addition, English language teachers need to have clear objectives for using this type of material so that they will choose the correct one for teaching different issues, as vocabulary for example. There is sometimes much vocabulary that is not relevant due to the scarce use of that terminology in real life.

\section{References}

Agudelo, J. (2007). An intercultural approach for language teaching. Developing critical cultural awareness. Íkala, Revista de Lenguaje y Cultura, 18(12), 185-217.

Alonso \& Fernández (2013). Enseñar la competencia Intercultural. In L. Ruiz de Zarobe \& Y. Ruiz de Zarobe (Eds.), Enseñar hoy una lengua extranjera (pp. 185-220). Berkeley: Portal Education.

Brinton, D. M. (1991). The use of media in language teaching. In M. Celce-Murcia (Ed.), Teaching English as a second or foreign language (2nd Ed.) (pp. 459-476). Boston: Heinle and Heinle Publishers.

Byram, M. (2002). Intercultural Competence in foreign languages: The intercultural speaker and the pedagogy of foreign language education. In D. K. Deardorff (Ed.). The Sage handbook of intercultural competence (pp. 321-332). Thousand Oaks, CA: Sage. 
Authentic Materials and Tasks as Mediators to Develop EFL Students' Intercultural Competence

Byram, M., Gribkova, B., \& Starkey, H. (2002). Developing the intercultural dimension in language teaching: A practical introduction for teachers. Strasbourg, FR: Council of Europe.

Cheung, C. (2001). The use of popular culture as a stimulus to motivate secondary students' English learning in Hong Kong. ELT Journal, 5(1), 55-61.

Cope, B., \& Kalantzis, M. (Eds.) (2000). Multiliteracies: Literacy learning and the design of social futures. London: Routledge.

Cortazzi, M., \& Jin, L. (1999). Cultural mirrors. Materials and methods in the EFL classroom. In E. Hinkel (Ed.). Culture in Second Language Teacbing and Learning (pp. 196-219). Cambridge: Cambridge University Press.

Council of Europe. (2001). Common European framework of reference for languages: Learning, teaching, and assessment. Cambridge: Cambridge University Press.

Freeman, D. (1999). Doing teacher research: from inquiry to understanding. Pacific Grove: Heinle \& Heinle.

Gebhard, J. G. (1996). Teaching English as a foreign language: A teacher self-development and methodology guide. Ann Arbor: The University of Michigan Press.

Gómez Rodríguez, L. F. (2015). The cultural content in EFL textbooks and what teachers need to do about it. Profile: Issues in Teachers' Professional Development, 17(2), 167-187.

Granados-Beltrán, C. (2016). Critical interculturality: A path for pre-service ELT teachers. Íkala, Revista de Lenguaje y Cultura, 21(2), 171-187.

Guariento, W., \& Morely, J. (2001). Text and task authenticity in the EFL classroom. ELT Journal, 55(4), 347-353.

Hymes, D. (1996). Ethnography, linguistics, narrative inequality. Bristol, PA: Taylor and Francis.

Kilickaya, F. (2004). Authentic materials and culture content in EFL classrooms. The Internet TESL Journal. Available at: http://iteslj.org/Techniques/Kilickaya-AutenticMaterial.html

Kramsch, C. (1998). Language and culture. Cambridge: Cambridge University Press.

Kumaravadivelu, B. (2003). Understanding language teaching. New Jersey: Routledge.

Mishan, F. (2005). Designing authenticity into language learning materials. Bristol, UK: Intellect.

Nunan, D. (1999). Second language teaching and learning. Boston: Heinle and Heinle Publishers.

Patton, M. (2002). Qualitative research and evaluation methods ( ${ }^{\text {rd }}$ Ed.). California: Sage Publications, Inc.

Porter, D., \& Roberts, J. (1981). Authentic listening activities. English Language Teaching Journal, 36(1), 37-47.

Ramos, B. (2013). Towards the development of intercultural competence skills: A pedagogical experience with pre-service teachers. HOW Journal, 20(1), 206-255.

Richards, K. (2003). Qualitative inquiry in TESOL. UK: Palgrave Macmillan.

Rico, C. (2012). Language teaching materials as mediators for ICC development: A challenge for material developers. Signo y Pensamiento 6o - Documentos de investigación, 30(60), 130-145.

Robinson, G. (1988). Cross cultural understanding. Cambridge: Cambridge University Press. 
Sellami, A. (2000). Teaching towards cultural awareness in intercultural competence. Paper presented at the annual meeting of teachers of English to speaker of other languages. Vancouver, Canada.

Shoomossi, N., \& Ketabi, S. (2007). A critical look at the concept of authenticity. Electronic Journal of Foreign Language Teaching, 4(1), 149-155.

Thanasoulas, D. (2001). Motivation and motivating in [the] EFL classroom. Available at: https:// www.englishclub.com/tefl-articles/motivation-motivating-efl.htm

Tudor, I. (2001). The dynamics of the language classroom. Cambridge, UK: Cambridge University Press. 